\title{
Apocalypse Now
}

\author{
Om telenærvær, cyborgs, medier og kunst
}

\author{
JACOB WAMBERG
}

\section{Indledning}

Når man forsøger at gøre op, hvordan kunsten blev autonom, støder man uvægerligt på en parallelhistorie, den om mediernes opdagelse i kunsten. En væsentlig modstand mod uafhængige, bagvedliggende og dermed kunstfremmede budskaber udfandtes nemlig i selve kunstens materielle grund, i det faktum at det kunstneriske indhold altid var medieret. For når mediets hvordan blandede sig i indholdets hvad, blev de to parter så ikke i sidste ende uopløselige? Spørgsmålet udsprang af en idé om, at hver kunstart - eller medium - besad grundegenskaber, som kunstværkerne måtte forholde sig til, hvis ikke deres indhold skulle forvrænges eller overses. Ved projektets begyndelse i I70o-tallets midte bedyrede Lessing eksempelvis, at litteraturen, især digtningen, bedst gengav tidslige forløb, hvorimod maleriet skulle fremstille rumlige forhold fastholdt $i$, hvad han betegnede svangre øjeblikke. ${ }^{I}$ Ved kunstautonomiens erklærede højdepunkt hos den amerikanske kunstkritiker Clement Greenberg to århundreder efter havde litteraturen imidlertid fået tildelt et sådant monopol på naturalistisk repræsentation, den angivelige hovedkilde til kunstfremmed forurening, at modernistisk skulptur og maleri gjorde bedst $i$ at gøre som musikken: bortskrælle naturalismen og forholde sig til deres mediers rene stoflighed, her hhv. voluminer og linier, farver og flade. ${ }^{2}$

I dag er det let nok at fremhæve svaghederne ved en sådan medieessentialisme. Efter at modernismens efterfølgere, neoavantgarderne og postmodernismen, har boltret sig i medier af alle slags - et orgie, der kun er blevet yderligere promiskuøst efter de digitale multimediers entré på kunstscenen - finder mange, at tanken om mediers iboende egenskaber som medbestemmende for kunstens indhold er en $\mathrm{i}$ bedste fald underholdende saga. Og alligevel kan man stadig støde på kunstformer, hvor mediet, selve den iklædning kunstværket optræder i, synes at blande sig i værkets betydningsrum i en grad, at mediet næsten, med medieteoretikeren Marshall McLuhans formulering, bliver identisk med budskabet. 3 Tag for eksempel kaninen Alba, der lyser grønt, når den udsættes for ultraviolet eller blåt lys, fordi dens skaber, eller snarere: medskaber, den brasilianskfødte Eduardo Kac, lod genetisk materiale fra selvlysende gopler overføre til dens mors kønsceller 4 - er der ikke allerede sket afgørende ting med betydningsrummet, derved at mediet i bogstaveligste forstand er blevet levende? Eller hvad med Ken Goldbergs installation TeleGarden (I995f.), hvor en haves beplantning og pleje er overladt til internetbrugere, hvis signaler omsættes til handling gennem havens eneste gartner, en fjernstyret robot 5 - er hele betydningsrummet ikke her igen næsten nedsmeltet i mediet, der på sin side omfatter et helt interaktionsfelt fra computerbrugere over internet til robot og have?

Når værker som disse kan virke så provokerende allerede gennem deres mediemæssige fremtoning, er det for mig at se, fordi de sammenfletter to virkelighedsområder, der traditionelt, og med følgevirkninger helt ind $\mathrm{i}$ avantgarderne, har været anset for kunstfremmede: på den ene side det organiske, på den anden side det teknologisk-funktionelle. Selv om jeg skal opfatte avantgarderne som i hovedsagen en forudsætning for denne type kunst, har avantgardekunsten i praksis ofte fortrængt det organiske til 
fordel for det teknologiske, og samtidig har dette teknologiske, trods mange intentioner om det modsatte, alene optrådt metaforisk og ikke funktionelt. Hvorimod altså disse værker lader liv og teknologi binde sammen $\mathrm{i}$ en egentlig funktionel udfoldelse, man kunne beskrive ud fra cyborgen, den organiske maskine. Faktisk kan man spørge, om ikke denne funktionelle udfoldelse - idet den måske kan opfattes som en ny underkategori af totalfænomenet virkeligheden - i grunden transcenderer det rent mediemæssige, så det mediemæssigt provokerende ved ovennævnte værker til dels består i, at mediet er absorberet af den virkelighed, det skulle bære vidnesbyrd om. Et medium kunne nemlig defineres som en passage for en semiotisk kode, dvs. en kode, der erstatter faktisk fravær med simuleret nærvær, men i ovennævnte værker er der ikke længere - i hvert fald ikke udelukkende - tale om simuleret nærvær. For billedet er jo gået i ét med Albas levende og højst nærværende krop, ligesom signalerne fra TeleGardens skare af fjerngartnere ikke bremses gennem skærmens semiotiske henvisninger til dem, men kanaliseres direkte over $\mathrm{i}$ hortikuturel handling.

I artiklen her skal jeg forsøge en analyse af udvalgte kunstværker, der tilhører dette mediemæssigt udvidede felt, som man dels kunne beskrive ved den organisk-maskinelle kimære, cyborgen, dels det afstandsovervindende handlingsrum, telenarvaret. Den analytiske optik skal være todelt, idet den på den ene side behandler værkerne ud fra en rumlig synsvinkel - hvor telenærværet bygger bro over de store afstande, cyborgen over de små - på den anden side undersøger dem ud fra en tidslig, tilblivelsesmæssig synsvinkel, jeg kalder evolutionisme. I et større tidsligt perspektiv er jeg nemlig af opfattelsen, at cyborgen er symptomatisk for opkomsten af en ny historisk udviklingsfase, den posthumane, der lader menneskets kulturhistorie krydse og smelte ind $\mathrm{i}$ den biologiske evolution, denne kulturhistorie hidtil har været udgrænset fra. Med fremkomsten af det posthumane udjævnes således forskellene mellem kulturelt producerede artefakter og naturligt tilvirkede genstande, hvorved naturens reservoir af organismer, herunder menneskekroppen, åbner sig for teknologisk medieret evolution - hvoraf Alba kunne udgøre et æstetisk appellerende pionéreksempel. Samtidig indebærer det posthumane en hyperkommunikativ tilstand, hvor kroppe kan vekselvirke fysisk over store afstande uden at blive afbrudt af bevidsthedens hidtil skærmende relæ - med andre ord telenærværet, hvoraf TeleGarden er udrundet. Disse mediemæssige betingelser synes, som antydet, ikke at lade kunstens ontologi uberørt, så artiklen skal derfor udmunde $i$ et bud på spørgsmålet om, hvilken status kunsten og det æstetiske mon kan optage i det posthumane. Kan kunsten, hvis den skal vedblive at være kunst, tåle at blive $\mathrm{i}$ så radikal grad virkeliggjort som her, eller kræver den fremdeles en beskyttende hinde af det imaginære?

\section{Mediernes lille naturhistorie}

For at kunne bedømme det nye ved de nye medier, der altså måske knap nok længere er medier, og følgerne for kunstens brug heraf, vil jeg indledningsvis skitsere en mediernes lille naturhistorie, en skematisk oversigt over forholdet mellem krop og medier, medier og teknologi, samt medier og kunst. Samtidig med at jeg her vil slutte mig til Marshall McLuhans idé om, at teknologi og medier generelt kan anses for forlængelser af den menneskelige krop, "extensions of man", 6 vil jeg også forsøge en differentiering, der beskriver teknologien i almindelighed som proteser for kroppen og medierne i særdeleshed som kunstige lemmer for sanserne og disses bearbejdning gennem intellektet (se diagram). Denne differentiering, vil jeg hævde, angår i sig selv et kulturskabt ekko af den differentiering, der allerede synes at udvikles i de mere komplekse biologiske organismer mellem på den ene side kroppen, der varetager direkte vekselvirkninger med miljøet som stofskifte, motorik og formering, og på den anden side sanseapparat og hjerne, der danner interne repræsentationer af miljøet, hvorudfra kroppen så kan reagere. Forskellen mellem krop og sanseapparathjerne er da, at hvor kroppen forholder sig umiddelbart handlende i sit miljø - spiser, fordøjer, ånder, bevæger sig, kopulerer, føder - der iværksætter sanseapparat og hjerne ikke direkte handling, men en dannelse af indre semiotiske billeder af fjernere forhold i miljøet, som organismen først indirekte kan 
omsætte i handling, når sanseapparat og hjerne giver besked herom til kroppen. Med følesans og smagssans som grænsetilfælde forholder sanseapparat og hjerne sig således til fænomener, der befinder sig på afstand af kroppen, og som denne derfor ikke umiddelbart kan vekselvirke med - en afstand, sanseapparat og hjerne imidlertid kan kompensere for ved at erstatte det faktiske fravær med et illuderet nærvær.

Mens mennesket er identisk med de mere komplekse dyr - fisk, fugle, øgler, pattedyr - hvad angår disse forhold, skaber det sig øjensynligt en særniche i dyreriget ved to nye kompetencer: dels kan dets hjerne generere repræsentationer af forhold, der ikke engang længere er umiddelbart til stede i dets fjernere omverden - fremtid, fortid, andre subjekters følelser og tanker, begreber, hypoteser, under ét hvad man kunne kalde forestillinger - dels fremstiller det i vekselvirkning med denne udvidede semiose teknologi, dvs. omstruktureringer af omgivelserne, der, som McLuhan bemærker, udvider dets kropslige rækkevidde og kapacitet. Her er det, jeg vil skelne mellem teknologi i almindelighed, der udvider kroppen og dens direkte omgang med verden - redskaber øger eksempelvis kroppens muskelkraft, huse og tøj dens varmeregulering, transportmidler dens mobilitet, kogekunst dens fordøjelse - og så medierne, der specifikt udgør proteser for sanseapparat og hjerne. På samme måde som sanseapparat og hjerne skaber indre semiotiske repræsentationer af faktiske eller imaginære forhold, sådan fremstiller medierne ydre semiotiske repræsentationer af de samme fænomener. Med tungemål og kropssprog som grænsetilfælde kunne medierne således defineres som kulturskabte, kropseksterne passager for tegn, der omdanner faktisk fravær til simuleret nærvær. Efter 
kulturanalytikere som Roland Barthes har udvidet det semiotiske felt til at omfatte hele den kulturskabte sfære, er der ganske vist ikke længere noget kulturskabt, der kan fraskrives mediemæssige egenskaber - tænk på mode, vaskemaskiner, design i almindelighed - og alligevel mener jeg, man kan skelne mellem artefakter, der primært er tiltænkt som medier (fx bøger, malerier og fjernsyn) og så artefakter, der tilhører den bredere teknologiske kategori, men derudover kan tilskrives en mediemæssig dimension ( $\mathrm{f} x$ en folkevogn, der udvider kroppens bevægelighed, men samtidig signalerer moderne, standardiseret velfærd). Indtil I9oo-tallets medieeksplosion, som jeg gemmer lidt endnu, kan man inden for primærmedierne gøre iagttagelsen, at talte ord eller skrevne tekster har besiddet det største spektrum for generering af simulerede sanseindtryk og abstrakte forestillinger, eftersom ordene ikke er direkte sanseligt bundet til de forestillinger, de fremvækker, men betjener sig af konventionelle tegn, der først skal oversættes gennem mental aktivitet. Traditionelle billedmedier som maleri og skulptur og lydmedier som musikinstrumenter, derimod, påvirker os direkte med sanseindtryk, der er analoge med vores indre mentale repræsentationer.

Ser man på de mere komplekse, bystatsbaserede civilisationer - i Vesten kulturerne siden antikken synes et fællestræk for deres medier endvidere at være, at de $\mathrm{i}$ altovervejende grad er baseret på fjernsanserne syn og hørelse, hvorimod nærsanserne lugt, smag og følelse øjensynlig ikke har fundet specifikt mediemæssige kanaler. Denne kulturelle tilstand stemmer tankevækkende overens med en neoplatonisk tradition, hvor sanserne ordnes hierarkisk efter, hvor de rent fysisk befinder sig mellem intellektet øverst og kroppen nederst. 7 Med deres nærhed til hjernen vil fjernsanserne syn og hørelse her fremstå som de mest åndelige, mens nærsanserne lugt, smag og følelse taber åndelig højde, i takt med at de i bogstavelig forstand nærmer sig kroppen. Medier kunne således beskrives som proteser for det oprejste menneske, der skuer og lytter mod verden fra imaginationens ophøjede afstand.

Disse indrømmet noget grovskitserede grundegenskaber ved medierne og deres forhold til krop- pen turde nu få betydning for min kunstdiskussion, eftersom jeg vil hævde, at kunsten traditionelt, dvs. indtil I900-tallets avantgarder, har udgjort et delområde af medierne. I forlængelse af mine indledningsvise bemærkninger vil jeg nærmere mene, at kunsten dannede sit særområde inden for mediets blot kommunikationslystne arena, idet den begyndte at undersøge forholdet mellem mediets materialitet, selv dets mediering, og så det betydningsrum, denne mediering kunne tolkes som bærer af. Hvis vi medtænker den ovennævnte beskrivelse af medier som proteser for sanseapparat og hjerne, turde denne definition i hvert fald stemme overens med I70o-tallets indkredsninger af den æstetiske erfaring, der netop henlagdes $\mathrm{i}$ det ubestemmelige mellemrum mellem sansning (jf. aisthetikos = sansende) og kognition, og som kunne angå både vores umiddelbare omverdenserfaring og så den omverdenserfaring, der videregives indirekte gennem kunstmediernes proteser. I æstetikkens grundlagsværk, Baumgartens ufuldendte Aesthetica (1750), indkredses poesien således som en diskurs, der er sammensat af konfuse ideer, eftersom de er bundet til sanserne i modsætning til videnskabens mere abstrakte og derfor distinkte og klare tale. ${ }^{8}$ Tilsvarende stiller Kant den rene fornufts systematiske begrebsliggørelser op mod den æstetiske erfaring, hvor forstandens begreber løsrives fra systemerne og indgår i fri og legende harmoni med den sanseformidlende fantasi. 9 Igen må det bemærkes, at den sansning æstetikken og kunsten her appellerer til, fortrinsvis vedrører de øvre, afstandsprægede sanser, syn og hørelse (jf. billedkunst, teater, litteratur, musik), og at de nedre, kropsnære sanser kun lader sig genskabe via de øvre (fx smagsoplevelser gennem ord, føling gennem synsindtryk af skulptur). Denne afstand til kroppen forstærkes af, at den føravantgardistiske kunst som regel har vist sig i afgrænsede og let overskuelige mødeflader: maleriets lærred, skulpturens afgrænsede klump, bog- og nodesidens papirark, orkesterets og teatrets scene en tendens, der via filmens og fjernsynets skærme fortsætter helt til nutidens computerinterface. Arkitekturen udgør her et grænsetilfælde, men man kan samtidig spørge, om der egentlig er tale om et medium i primær forstand, et simuleret nærvær, der 
erstatter et faktisk fravær, og ikke snarere om en artikulation af det reelt omgivende rum.

At den æstetiske erfaring traditionelt er tilskrevet de øvre sanser og intellektets regioner og udgrænser sig fra den underliggende krop, bekræftes også gennem Kants krav om interesseløshed, idet denne nemlig kunne forstås som frihed for kroppens interesser, dvs. begær i bredeste forstand fra seksuel tiltrækning over appetit til besiddelsestrang. Denne lodrette kontrast mellem sansende hjerne og krop kan samtidig udvides i vandret retning til kroppens protese, teknologien, for når Kant bemærker, at det æstetiske omhandler en formålsrettethed uden formål, kan det forstås som en formålsrettethed løsrevet teknologiens nyttefunktion, nemlig en funktion, der går kroppens ærinde ved at udvide dens aktionsradius. Fra dette kropsfjerne, æstetiske perspektiv bliver det særlig forståeligt, hvorfor kroppen kan underlægges den samme mekanistiske og materialistiske tale som teknologien - en tale, der indførtes med Descartes og kulminerede i de kommunistiske regimer, hvis yderste ideal da kunne siges at omhandle kropsmaskinens behovsopfyldelse. De kapitalistiske samfund, derimod, har som yderste ideal efterstræbt en mere immateriel form for behovstilfredsstillelse, individets frie selvbestemmelsesret, og her har den æstetiske erfaring, nydelsen af en sanselighed hævet over politikkens kamp om kroppene og deres teknologiske proteser, udgjort et vigtigt symptom.

\section{Telenarvaer og cyborgs: Indledende bemarkninger}

På baggrund af dette lille rids af det klassisk moderne forhold mellem medier, kunst og krop, er det nu mit håb, at man nemmere vil forstå det radikalt grænseoverskridende potentiale i eksperimenterne med cyborgs og telenærvær, ikke mindst i forhold til den vanlige opfattelse af æastetik som bundet til fjernsanser og kunst som en særlig form for medieudforskning. Selv om jeg mener, at disse nye fænomener gror ud af dels I8-I9oo-tallets udvikling af elektriske medier, dels avantgardernes kunst, vil jeg af anskuelighedsgrunde springe direkte til de seneste og ofte futuristisk associerende eksperimenter, og så først bagefter knytte udvalgte tråde tilbage i historien. For at videreføre den hidtidigt opbyggede tankegang vil jeg sige, at der er ved at ske to afgørende bevægelser med medierne og teknologien i det hele taget:

I) I telenarvaret bliver mediernes præg af et simuleret nærvær, der erstatter et faktisk fravær, udfordret, idet man nu kan møde en signaloverførsel, der ikke først skal tolkes af en bevidsthed for at blive omsat til handling, men kanaliseres direkte ud i virkeligheden. Herved udjævnes det ovennævnte skel mellem medium og teknologi i al almindelighed, eftersom teknologien jo skilte sig ud fra mediet ved $\mathrm{i}$ lighed med kroppen, men modsat sanseapparat og hjerne, at indebære en direkte vekselvirkning med verden. Den afstand, som mediet overvandt med en imaginær bro, udfyldes nu af noget, der derfor mere skal sammenlignes med en organprotese end med en sanseprotese, hvorved mediet allerede definitionsmæssigt er udfordret.

2) Ud over denne tilnærmelse mellem medium og teknologi møder man endvidere, og måske endnu mere radikalt, en konvergens mellem krop og teknologi, den bevægelse, der udmunder i cyborgen, den organiske maskine. Herved nedbrydes både mediets og teknologiens præg af protese, en kunstig og fra kroppen adskilt løsdel, der nok efterligner, men ikke desto mindre, som endnu i den klassiske modernitet, er ontologisk forskellig fra krop, sanser og hjerne. I stedet opstår et fællesrum, hvor der ikke længere kan skelnes mellem det konstruerede, overfladiske, frembragt indirekte gennem bevidsthedens, mediets og teknologiens mellemkomst, og det naturskabte, indre, genereret $\mathrm{i}$ et lukket kredsløb gennem direkte kropslig vekselvirkning.

Selv om de to kategorier, telenærvær og cyborg, om ikke andet for det analytiskes skyld skal forsøges adskilt $\mathrm{i}$ det følgende, fornemmer man tydeligt, de er beslægtede. Hvor telenærværet overvinder store fysiske afstande ved at forvandle mediet til handlekraftig teknologi, overvinder cyborgen de små fysiske afstande, dvs. tilnærmer denne teknologi til vores krop, sanser og hjerne. På denne måde skabes netværker, der på paradoksal vis udfordrer mange af vores kul- 
turbærende dualismer ved at gøre de respektive poler lige betydningsfulde eller sande: afstand-intimitet, middelbar-umiddelbar, medium-teknologi, teknologi-krop, kultur-natur, konstrueret-selvgroet, hjernekrop og hvem ved, måske også kunst-liv.

\section{Telenarvar og kunst}

Begrebsligt forbinder telenærvær to sfærer: på den ene side telematik, der omhandler transmission af tegn over afstand, på den anden side robotik, tilvirkningen af kunstige kroppe. I modsætning til navigation i cyberspace, hvor den menneskelige bevidsthed via krop og interface vekselvirker med et virtuelt rum, en ren simulation af den fysiske verden, inddrager telenærværet et eller flere virkeligt eksisterende steder, som aktører kan påvirke og påvirkes af, gennem 'udstationerede' kunstige lemmer og sanser, der gør den fjerne virkelighed nærværende for dem. Som det så ofte er tilfældet med konsekvensrige nye opfindelser, blev et sådant kredsløb første gang beskrevet i science fiction sammenhæng, nærmere bestemt i Robert Heinleins lille roman Waldo fra 1942. Her læser vi om geniet Waldo F. Jones, der som følge af en muskelsvækkende sygdom bygger sig et vægtløst hus i kredsløb om jorden og herfra udfører teleoperationer på jordoverfladen. Det foregår ved, at Waldo nøjes med at bevæge sine svage arme og fingre i det tyngdeløse rum, hvorefter en særlig hardware, de såkaldte 'waldoes', overfører hans kropssignaler til en serie jordisk anbragte robothænder, hvis forskellige størrelse tilpasses hans videobriller, så han synes at rse sine egne hænder i aktion. ${ }^{\text {IO }}$ Da selve ordet 'telenærvær' (eng. telepresence) lanceres i en pionerartikel af robotforskeren Marvin Minsky fra 1980 , har det nu fảet mere normallegemlige og jordbundne associationer og forudses forbundet med udviklinger inden for minering, atomenergi, dybvands- og rumforskning, eksempelvis en permanent månerobot fjernstyret fra jorden. ${ }^{\text {II }}$

For Eduardo Kac (f. 1962), en af pionererne inden for kunst, der udforsker telenærvær, og samtidig en af dens mest perspektivrige fortolkere, er det imidlertid hverken mulighederne for at udføre bestemte opgaver eller den forbløffende følelse af at 'være der', som tiltrækker. Snarere ser han telenær- værskunst som et middel til at udfordre de envejsbestemte kommunikationsstrukturer, der præger både finkunst som maleri og skulptur og massemedier som tv og radio:

Jeg ser telenærværskunst som en måde, hvorpå man kan skabe en åben og engagerende erfaring, der manifesterer de kulturelle forandringer, som er afstedkommet af fjernstyring, fjernsyn, fjernbevægelse og real-time-udveksling af audiovisuel information. Jeg ser telenærværskunst som noget, der udfordrer teknologiens teleologiske natur. For mig skaber telenærværskunst en unik kontekst, hvor deltagere oplever opfundne fjernverdener fra perspektiver og skalaer forskellig fra de menneskelige, sådan som det sker gennem telerobotters sanseapparater. Rytmerne, der skabes af denne nye kunst, vil blive styrket af intuitive interfaces, linking- og netværksbegreber, telerobotdesign og konstruktion af fjernmiljøer. ${ }^{12}$

Telenærværet har han bl.a. udforsket i Ornitorrinco, et robotprojekt, der i samarbejde med teknikeren Edward Bennett er blevet udviklet siden I989, hvor Kac slog sig ned i Chicago. Ornitorrinco (portugisisk for næbdyr) er en halv meter høj, ledningsløs robot, der lader sig fjernstyre af forskellige aktører, først via telefon og videofon, siden 1994 også via internettet. I installationen Ornitorrinco on the Moon (1993) fx kunne brugere på Künstlerhaus i Graz telefonisk påvirke robottens bevægelser i School of the Art Institute of Chicago - I betød 'til venstre', 2 'fremad' osv., og pressede man 5 kom der, med seks sekunders forsinkelse pga. telefonens dengang lave båndbredde, et billede frem på en videoskærm, der gengav robottens nuværende synsfelt. ${ }^{13}$ En senere installation, Ornitorrinco, the Webbot, travels around the world in eighty nanoseconds going from Turkey to Peru and back (I996), lod robotten dele rede med to kalkuner i Otso Gallery, Espoo, Finland. ${ }^{14}$ Her kunne deltagere veksle mellem fjernkontrol på internettet, nærkontrol fra galleriets første sal og betragtet interaktion i kælderen, når de prøvede at komme i kontakt med robot og kalkuner på den anden side af en glasvæg. I et interview fremhæver Kac, hvordan $\mathrm{Or}$ nitorrinco-installationerne således tillader den enkelte af skifte standpunkt:

Hvad telenærværsinstallationen med Ornitorrinco-robotten 
handler om, er metaforisk at opfordre beskueren til at kigge på verden fra en andens synspunkt. Det er en ikke-metafysisk udaf-kroppen-oplevelse, om man vil. Man opfordres til at flytte sig fra éns direkte erfaring af rummet, der omgiver én, og transportere sig, i tid og rum, til en anden krop, til en anden situation, til en anden identitet. Man opfordres til at anbringe sig $i$ en andens sko... ${ }^{\text {Is }}$

Som det understreges af en anden Kac-installation, Rara Avis, er denne fremmede krop, man transporteres til, ofte af en ubestemmelig beskaffenhed, der peger mod en udviskning af grænserne mellem maskinelt og dyrisk. ${ }^{16}$ I et stort fuglebur, blandt tredive finker, havde Kac her opstillet en stor, papegøjelignende fugl, en telerobot med CCD-videokameraer til øjne. Gennem et par videobriller foran buret kunne beskueren nu opleve installationen fra robotfuglens perspektiv, herunder dens hovedbevægelser, der gentog beskuerens, ligesom internetbrugere via mikrofoner kunne lave lyde ud af fuglerobottens mund. På den vis kunne adskillige personer, i lighed med Ornitorrinco-installationerne, dele fuglerobottens krop, samtidig med at man kunne være både fysisk uden for og vikarielt inden for buret.

En anden kunstner, der både konkret har udforsket og skrevet om implikationerne $\mathrm{i}$, hvad han kalder 'tele-epistemologi', er Ken Goldberg, professor i robotik ved University of California. Også for Goldberg er en central egenskab ved telenærværet, at det udfordrer vores overleverede forestillinger om virkeligheden.

"Hvordan ved jeg, at dette er virkeligt?” Beskueren handler og sanser denne "virkelighed" gennem et instrument uden objektiv skala. Hvordan adskiller den indrammede vision $i$ et instrument som mikroskopet sig fra den indram- ning, der udbydes med Wold Wide Web? ${ }^{17}$

spørger Goldberg og nærer spørgsmålet med den indledningsvist nævnte installation TeleGarden, der blev præsenteret på University of Southern California i 1995 og året efter flyttet til sit nuværende grosted, Ars Electronica i Linz. ${ }^{18}$ Den eneste adgang til at påvirke TeleGardens trivsel er således via Internettet, der er forbundet med en industriel robot, hvis roterende arm sender fotografier fra haven og på fjerngartnernes initiativ graver huller, dropper sædkorn og vander. Selv om det står frit for alle at få medlemsskab til haven og gøre med den, hvad de vil, håber Goldberg og hans team, at projektets karakter vil skabe en kollektiv ansvarlighed - at skaren omkring haven så at sige rykker fra nettets dominerende jæger- og samlerkultur til en agerbrugskultur, hvor rumlig og tidslig kontinuitet er af betydning. Derfor er haven også forsynet med et chatforum, den såkaldte village square, hvor brugerne kan mødes og drøfte havens udvikling.

Fælles for telenærværsinstallationer som disse er 
igen, at de alle udfordrer min ovennævnte mediedefinition, mediet som en passage for tegn, der erstatter faktisk fravær med simuleret nærvær. For afstanden, der skiller subjekt fra referent, indebærer ikke, som ved vanlige medier, en handlingsmæssig impotens over for referenten, snarest virker teknologien som krops- snarere end sanseprotese, således at beskueren forvandles til agerende. Som Kac bemærker, kunne man derved i telenærværet se et kriterium for, at Baudrillards hyperrealitet griber om sig, for hyperrealiteten defineres netop som en tilstand, hvor der ikke længere er nogen absolut afstand mellem tegn og referent, medium og realitet:

Mediet selv er ikke længere identificérbart som sådant. [...] Der er ikke længere noget medium i bogstavelig forstand: det er nu uhåndgribeligt, diffust og spredt i det virkelige, og det kan ikke engang længere siges, at sidstnævnte fordrejes af det. ${ }^{19}$

Også for Paul Virilio er de syntetiske billeder blevet så invaderende, at vi oplever en sammensmeltning af "det faktuelle (eller om man vil, det operationelle) og det virtuelle", og samtidig er der tale om "et paradoksalt narvar, et genstandens eller det levende væsens tele-nærvær over afstand, der her og nu træder i stedet for selve deres eksistens." ${ }^{20}$ Som følge af teknologiens accelererende formidling af signaler bemærker Virilio også, at afstandene i det fysiske rum mister deres betydning og erstattes af et dominerende nærvær af reel tid. ${ }^{2 I}$ Modstanden, der skal overvindes i satelittens og fiberoptikkens tidsalder, måles ikke så meget i kilometer i timen som i bits pr. sekund, og når den nedbringes, forstår man det umiddelbares dobbelte hentydning til øjeblikkelighed og manglende mediering. ${ }^{22}$ Informationsteoretikeren Abraham A. Moles bemærker om denne vikarielle, realtidslige tilstedeværelse, at den ødelægger

det organiserende princip, hvorpå vores samfund hidtil har været konstrueret.Vi har kaldt dette princip nærhedens lov: hvad der er tæt på, er vigtigere, sandere eller mere konkret, end hvad der er længere væk, mindre og sværere at få adgang til [...]. Fra nu af tilstræber vi en livsmåde, hvor distancen mellem os og objekterne bliver irrelevant for vores bevidsthedstilstand. I denne henseende indebærer telenærvær også en følelse af ens afstand for enhver fra alle andre, og fra hver af os til en hvilkensomhelst hændelse i verden. ${ }^{23}$

Kunne Lars von Triers og Niels Vørsels installation Verdensuret: Psykomobile \#1, der udførtes på Kunstforeningen i København i efteråret 1996, ikke tolkes som en kunstnerisk udforskning af denne forbundethed mellem os og verden på tværs af alle fysiske afstande, størrelsesforskelle og biologisk-kulturelle tilhørsforhold? Et videokamera opstillet ved en myretue i en ørken ikke langt fra El Paso, New Mexico, var her via en computer forbundet med nitten rum i Kunstforeningen, hvor treoghalvtres levende skuespillere gebærdede sig efter fire lampers skiftende konstellationer. Hver gang myrerne i New Mexico overskred en vis kritisk tærskel, ændredes lampernes farver, hvorpå skuespillerne indgik i nye uforudsete situationer, alliancer og følelsesmæssige forviklinger. ${ }^{24}$ Eduardo Kac og Ikuo Kakamura havde i 1994 lavet en beslægtet, omend noget mindre kompleks installation, hvor alene ikke-menneskelige aktører, en i Kentucky og en i New York, var i telematisk dialog. I denne installation, ironisk forsynet med den Hume'ske titel Essay Concerning Human Understanding, transmitteredes en kanariefugls sang til en fjern philodendron-plante, hvis vegeterende respons på sangen opfangedes af en elektrode og behandledes af et computerprogram, der ellers var beregnet til at registrere menneskelig hjerneaktivitet. Disse i egentligste forstand grøntsagsagtige signaler omsattes så til elektroniske lyde, der sendtes tilbage til kanariefuglen og stimulerede den til ny sang.

I installationer som disse understreges telenærværets almindelige anti-mediemæssige tendens, dets tekno-animalske direkthed, derved at det ikke behøver bevidstheden som nødvendigt relæ i sit kredsløb, men kan skabe handling og kommunikation alene ud fra motoriske eller kropsinterne signaler. Mange kunstnere har således også vendt sig mod det indre af menneskekroppen og forsøgt af fả teknologisk medieret dialog med den uden om bevidsthedens censur - eksempelvis musik frembragt ud af hjernens eksternt målte signaler (David Rosenboom) 
eller kommunikation skabt alene gennem hjerteslagets rytmer (Catherine Richards). ${ }^{25}$ Mest radikal i denne henseende er nok den australske performancekunstner Stelarc, der ved flere lejligheder - eksempelvis 'Telepolis' Fractal Flesh (1995) og ParaSite: Event for Invaded and Involuntary Body (1997) - har koblet sin krop til internettet og overladt visse af dens bevægelser til fjernagenter eller blot automatiske programmer. Elektroder sættes på udvalgte muskler, og gennem fjernpåvirkninger, der omsættes i strømstød på op til 6o volt, foretager Stelarc ufrivillige bevægelser, der kunne lede tanken til Galvanis eksperimenter i I700-tallet, hvor døde frøers lår spjættede gennem elektriske stød. For Stelarc indgår disse performances, hvor død frø er afløst af levende menneske, i en pejling mod den angiveligt forestående posthumane epoke, hvor menneskekroppen vil åbne sig for teknologien og blive vært for en mangfoldighed af fjernagenter, deplacerede nærvær. ${ }^{26}$ Med Stelarcs ord: "Begæret efter at lokalisere selvet simpelthen inden for en særlig biologisk krop er ikke længere meningsfuldt.” ${ }^{27}$

\section{Cyborgs og kunst}

Fra telenærværets brobygning over de store afstande skal jeg nu bevæge mig til cyborgens sammenkitning af de små ${ }^{28}$ - til et fokus, der fremhæver, hvordan grænserne i tiltagende grad udviskes mellem kold teknologi og varm organisme, og hvordan denne grænseudviskning udforskes af en samtidskunst, der hverken er bange for at udbygge sin hidtidige interesseløshed med teknologiens nyttefunktion eller livets etik. Hvis telenærværet pegede mod en vekselvirkning i realtid, kan cyborgen siges at intensivere forandringsmuligheden $\mathrm{i}$ denne realtid. Kulturens teknologi og dens bagvedliggende ideer - dem biologen Richard Dawkins har kaldt for memer $^{29}$ - indgår her $i$ en så tæt alliance med livets mindsteenheder, generne, at generne kan blive genstand for en memetisk påvirket, dvs. accelereret evolution - en hyperevolution, der ikke længere er afhængig af miljøets og den blinde mutations langsomme vekselvirkning, men kan lede memerne direkte over i generne. $3^{\circ}$ Evolutionens hidtidige udgrænsning $i$ artslinier med hver deres interne projekt opblødes herved af en tværgående promiskuitet, hvor gener og organer kan krydses på tværs af arterne og yderligere forbinde sig med kunstige dele, der efterhånden er udformet $\mathrm{i}$ samme sprog som dem selv. Det er i dette evolutionære perspektiv, hvor kulturskabt sammenflettes med naturskabt $\mathrm{i}$ cyborgen, at den posthumane epoke presser sig på, for menneskekroppen vil næppe holde sig fri af denne artificielt befordrede forandring.

Kulturhistorisk er cyborgen da også især møntet på en forandret menneskekrop. Konceptet udsprang af omtrent samme kultur som telenærværet, nemlig efterkrigstidens USA med dets fobi over for invaderende rumvæsener og paradoksalt samtidige drøm om at få mennesket ud i rummet. På New Yorks Rockland State Hospital kune man omkring 1960 møde to NASA-forskere, Manfred Clynes og Nathan Kline, der forsøgte at modificere mus, så de kunne modstå de barske forhold i det ydre rum. Målet var, hvad de kaldte cyborgen, den forhærdede menneskekrop. Denne neologisme, en forkortelse af 'cybernetic organism', sammenfører på den ene side kybernetik, Norbert Wieners nye tværgående videnskab om selvregulerende systemer, fra meteorologi over computere til levende væsener, på den anden side organisme. Den sigter til et menneske, der "gennem passende biokemiske, fysiologiske og elektroniske modifikationer" er artificielt opgraderet - som [...] "overlagt indbefatter ydre komponenter, hvorved det udvider organismens selvregulerende kontrolfunktion for at tilpasse sig nye omgivelser". ${ }^{31}$ Hvor Heinleins rumboer Waldo var en handikappet, der normaliseredes gennem telematisk overførte bevægefunktioner, er Clynes' og Klines' cyborg altså en normal, der opgraderes gennem interioriserede kunstige organer.

Selv om cyborgen dengang forblev et fantasme, der hurtigt blev opgivet af NASA, er den siden blevet en påtrængende figur, der breder sig i snart sagt alle egne af virkelighedens verden fra reagensglasbefrugtning, kloning og genmodificerede afgrøder over plastikkirurgi og transplantation af kunstige organer til kunstig intelligens, pervasive computing og nanoteknologi. Den er selvsagt også en genkommende figur i populærkulturen - tænk på Alien, Star 
Wars, teletubbies, Terminator, Kraftwerk - og denne dobbelte herkomst er særlig interessant $i$ et mediemæssigt perspektiv, når man nu iagttager, at cyborgen også presser sig på i mere eller mindre realiseret stand i den avantgardistisk sindede kunst. For så længe cyborgen optræder i populærkulturens billeder og overhovedet repræsentationernes sfære, er den underlagt medierne og deres spilleregler, men idet den træder ud i virkeligheden og bliver et livsdueligt væsen, sprænger den enhver semiotisk begrænset mediering, og det uanset om den indrammes som naturvidenskabeligt eksperiment, fødevare, medicinsk hjælpemiddel eller kunstværk. Den legemlige protesekraft, der allerede trak telenærværet ud af den rene mediesfære, udvides således kun i cyborgen, eftersom protesens funktionalitet her udbygges med det levendes habitat.

Kunstnerme i dette felt - heriblandt Joe Davis, Eduardo Kac, David Kremers, George Gessert, Oron Catts, Ionat Zurr, Brandon Ballangée, Laurie Stern og Natalie Jeremijenko - arbejder således i forskellige størrelsesforhold med biologiske materialer: gener, celler, bakterier, planter, dyr. Et pionerværk på det genetiske niveau, Joe Davis' Microvenus (1987), tog som udgangspunkt det samme motiv, som kendetegnede nogle af menneskets første billeder, nemlig et piktogram af en vulva. I cyborgens gode tradition om extraterrestriale ambitioner ønskede Davies at skabe et universelt budskab, og gennem en bitversion af primtal og DNA-basernes relative molekylvægte indkrypterede han derfor piktogrammet til et syntetisk plasmid, der derpå splejsedes ind i bakterien E.colis gener, hvor det angiveligt kan overleve menneskeheden. ${ }^{32}$ Det var også de store fortællinger, men måske $\mathrm{i}$ en mere ironisk version, der kommenteredes i Eduardo Kacs installation Genesis fra 1999. I kolibakteriernes DNA, der jo er skrevet i samme biokemiske sprog som menneskets, havde Kac denne gang indkrypteret en let modificeret passage fra Første Mosebog: "Lad mennesket herske over havets fisk og over himlens fugle og over enhver levende ting, der bevæger sig på jorden.” Også i denne installation var bakterierne imidlertid genstand for telenærværspræget medskabelse fra beskuernes side, idet man over en computer eller internettet kunne udløse et ultraviolet lys, der som i en skabelsesgnist fik den opprojicerede petriskål til at lyse blåt, mens de Genesismærkede bakterier lyste i cyan og de upåvirkede i gult. Herved accelererede man bakteriernes naturlige mutationshastighed, herunder det indkrypterede budskab, hvis tilbageoversatte forandring var opskrevet ved installationens udgang: "LET AAN HAVE DOMINION OVER THE FISH OF THE SEA AND OVER THE FOWL OF THE AIR AND OVER EERY LIVING THING THAT IOVES UA EON THE EARTH.”33 De levende skabninger lader sig åbenbart ikke sådan beherske og da slet ikke som pålideligt medium for menneskets 'evige' budskaber.

Hvis disse værker stadig lever $\mathrm{i}$ et spændingsfelt mellem cyborg og nyt medium for gammelkendte semiotiske budskaber, lod Kac cyborgen springe ud af medieskabet med projektet GFP Bunny, der er udviklet siden I998. Kac samarbejdede her med det franske INRA-laboratorium, der til medicinske formål overfører et modificeret gen fra stillehavsgopler til andre organismer. Genet, der kaldes GFP (for Green Fluorescent Protein), har den egenskab, at det får organismers celler til at lyse grønt, når de udsættes for blåt lys. Kac ønskede oprindelig at overføre genet til en hund, men i praksis blev det kaninen Alba, der i februar 2000 kom til at lyse grønt, efter hendes albinomor havde fảet indsplejset genet i sin nyundfangede kønscelle. Ifølge Kac udgør dette såkaldt transgeniske værk en forhandling af "terrænet mellem videnskab og kunst", en "undersøgelse af ideerne om normalitet, heterogenitet, renhed, hybriditet og andethed", og som transgeniske værker overhovedet må det ledsages af "en viethed til at respektere, nære og elske det således dannede liv". ${ }^{34}$ Kunstværket GFP Bunny består således ikke bare i selve den selvlysende kanin, men også i dens mange kontekster, heriblandt den offentlige dialog, den afstedkommer, og den tiltænkte sociale integration af kaninen i Kacs familie, der skulle ske, når den bragtes fra Frankrig til Chicago som kæledyr. Imidlertid er den sidstnævnte intention endnu ikke virkeliggjort, mens omvendt den offentlige dialog i Frankrig og USA er svulmet til uforudsete dimensioner, eftersom det franske forskningslaboratorium har lukket 'for- 
handlingen mellem videnskab og kunst' og tilbageholder Alba i videnskabens navn.

Dermed bekræftes kun alt for tydeligt Kacs synspunkt, at den bioteknologiske videnskab hidtil har været for lukket omkring en videnskabelig rationalitet, der næres af global kapital. I en tid, hvor der forsvinder mindst én biologisk art om dagen, mener Kac imidlertid, at kunstnerne kan bidrage til at udvide den globale biodiversitet ved at opfinde nye transgenetiske livsformer:

Etisk og ansvarlig interartslig skabelse vil afstedkomme udviklingen af smukke kimærer og fantastiske, nye levende systemer, såsom plantimals [planter med animalsk genetisk materiale eller omvendt] og animans [dyr med humant genetisk materiale eller omvendt]. 35

Interessant nok er det den tilsyneladende nytteløse, i hvert fald delvis æstetiske, dimension ved sådanne nye organismer, der virker så provokerende på mange og i særdeleshed skaber skrupler ved at slippe Alba ud af laboratoriet. Abstrakt set kendetegnes livets værdighed vel ellers ved, at det ikke er tingsligt og kan underlægges rene nyttehensyn, men når det kommer til artificielt tilvirkede dyre- og plantearter, er det åbenbart alene det brugsmæssige, der kan retfærdiggøre deres eksistens. Men måske gælder det kun, når graden af kunstighed overskrider en vis tærskel, den direkte genmanipulation, for ellers har store mængder dekorative planter, husdyr og dyr til sportsbrug gennemgået en overvejende æstetisk betinget forædlingsproces siden kulturens barndom. En af den genetiske kunsts foregangsmænd, lowtech-blomsterforædleren George Gessert, opfatter denne årtusindgamle forædlingspraksis som en "uerkendt generisk folkekunst eller primitiv genetisk kunst”, og han tilskriver den en overdådig fremtid, nu hvor generne kan påvirkes direkte..$^{6}$ En kunstner, der uventet tidligt bragte blomsterforædlingen fra low- til high-tech, var fotografen Edward Steichen, der udstillede sine genetisk ændrede riddersporer på New Yorks Museum of Modern Art i 1936. Blomsternes gigantstørrelse og hidtil uset strålende farver skyldtes, at de var dopede med colchicin, et middel Steichen ellers brugte mod sin gigt, men som nu viste sig at ophæve hybridplanters vanlige sterilitet og accelerere deres mutation. Med Steichens ord befordrede han dermed "naturens fremskridt" og forudså, at kunstnere efter ham ville "bringe os blomster hinsides alle vore nuværende begreber og forestillinger." 37

Den æstetiske ansporing til genetisk manipulation kan muligvis virke uskyldig, dvs. etisk forsvarlig, så længe forædlingens genstand udgøres af blomster, og til nød kaniner, men hvad nu når den gælder mennesker? Når Steichen huskes idag, er det ikke så meget for sine genetisk modificerede riddersporer, som for sin kuratering af fotografiudstillingen The Family of Man (1955), hvis budskab om menneskers beslægtethed på tværs af kultur og race skulle dulme sårene efter et vist mellemliggende eksperiment, hvor den forædlingsværdige blomst udgjordes af simulakret det ariske menneske. I i hvert fald ét samtidskunstnerisk eksperiment, der har en æstetisk betinget ombygning af mennesket på programmet, den franske performancekunstner Orlans plastikkirurgiske operationer, tages der således afstand fra en enhver eugenisk strategi. Orlan deler Stelarcs idé om, at vi er på vej ind i en posthuman epoke, hvor menneskekroppen er forældet, og ifølge hende vil det give os en frihed til at "ændre vores kroppe så let som vores hårfarve", ${ }^{8} \mathrm{dvs}$. gennem teknologiens mellemkomst at udjævne skellet mellem realkrop og efterstræbt image. Kropsombygningen vil for Orlan at se blive et personligt anliggende, der udfordrer enhver "påtvunget" platonisk idé eller tilhørsforhold til et "skønhedsbillede, der antages at være anvendeligt for alle". 39 Ikke desto mindre har hun i sin egen Art Charnel fra I990'erne ladet udvalgte forbilleder fra den mest kanoniserede kunsthistorie overføre til sit ansigt - en pande fra Mona Lisa, en kind fra Botticellis Venus, øjne fra Gérards Psyche etc. - men måske for at understrege, at dette er hendes originale appropriation, punkterede hun til sidst denne idealtskønne montage med to mefistofeliske buler i panden. Orlans ofte meget smertefulde kropsombygninger har udgjort et videotransmitteret anatomisk teater med effekter som blomster, læbestift, musik, egen oplæsning, læger i haute couture og sidenhen en relikvieagtig konservering af udvalgte operationsre- 
ster. I lighed med Kacs GFP Bunny er kunstværket Orlan således deplaceret mellem selve sin kunstigt opgraderede krop og de rumlige omgivelser, teletransmitterede billeder og diskursive felter, denne krop er indskrevet i.

Når Orlans kropsinterventioner trods alle posthumane tendenser stadig fremstår som egentlig forbavsende kantiansk æstetiske $\mathrm{i}$ ansatsen, er det, dels fordi de kan tilskrives hendes suveræne smagsdisposition, dels fordi de i praksis angår alene hendes ydre fremtoning hinsides funktionelle krav. Hos Stelarc søges dette felt sprængt, eftersom han på den ene side, som vi har set, lader sin krop åbne for fjerninducerede bevægelser, han ikke er herre over, på den anden side indgår $\mathrm{i}$ overvejelser og praktiske undersøgelser, der i det mindste i princippet angår kroppen som funktionel ansamling af organer, hvad han selv betegner "det operationelle". I denne mindre suverænt egostyrede version af det posthumane beskrives kroppen som evolutionært afmægtig over for den teknologisk infiltrerede kultur, den selv har skabt, hvorfor den presses til at ombygge sig selv til en cyborg, der har udskiftelige organer og kan vekselvirke mere direkte med andre cyborgs og med den fælles matrix, internettet.40 I Stelarcs performances repræsenteres de udskiftelige organer med eksempelvis den såkaldte Tredje Hånd, en robotprotese, der kobles til hans højre arm og styres af bugmusklerne, eller ved Exoskeleton, en tonstung seksbenet robot, hvis bevægelser - blandt andet af en antennelignende, forlængelig arm - igangsættes fra dens midte. Sidstnævnte, en arvtager af NASAs landingsfartøjer fra månen og Mars, kunne give associationer til den sværmintelligens, vi alle opsluges af som sociale, internetsurfende insekter - et indtryk, der dog samtidig udfordres af robottens påfaldende klodsethed og forpinte trykluftsstøn.4r Det posthumanes barsel er øjensynlig en tung affære.

\section{Mediemassige og avantgardistiske genealogier}

Fra disse udvalgte eksempler på kunst, der inddrager telenærvær og cyborgs, turde det være klart, at mediernes ontologi er på vej mod om ikke at blive undermineret, så dog kraftigt uvidet med noget, der faktisk ikke længere er medier. Mediernes simulerede nær-
Exoskeleton, Stelarc, 1998

vær overlejres her med reelle former for nærvær, hvilket dog paradoksalt nok ikke betyder en svækkelse, men tværtimod en styrkelse af teknologiens infiltration af det naturskabte. Tilsyneladende tilbagevindes det reelle kun via teknologiens mellemkomst.

Som tidligere antydet, indtræffer denne det reelles teknologiafhjulpne tilbagekomst dog ikke i et diskontinuert katastrofisk cusp, der pludselig flænger medierne og udgrænser dem til fortiden, snarere sker der en gradvis tilnærmelse mellem medier og virkelighed i løbet af I9oo-tallet, hvoraf jeg her vil fremdrage tre genealogiske linier inden for medierne og kunstens brug af eller brud med dem. I en fortsættelse af den medieessentialistiske tankegang fra indledningsafsnittet vil jeg således ironisk nok se et paradigmeskift med opkomsten af det, vi i dagligsproget forstår ved 'medierne', dvs. de masseprodu- 
cerede kommunikationsfora fra trykpresse til elektrisk og elektrononisk mediering, der griber om sig fra I80o-tallets midte. Denne kategori korresponderer med både Walter Benjamins 'tidsalder for mekanisk reproducerbarhed' og Marshall McLuhans 'elektriske tidsalder', ${ }^{2}$ og som jeg skal vise nedenfor, fremlæser disse teoretikere da også interessante grundegenskaber, der peger frem mod telenærværets og cyborgs'enes karakteristika. For kunstens vedkommende vil jeg se et korresponderende og ofte direkte vekselvirkende paradigmeskift med opkomsten af de bevægelser, der specielt siden Peter Bürgers kategorisering har gået under navnet 'avantgarde',43 dvs. bevægelser, der søger at bryde kunstens klassisk moderne autonomi og bringe den ud i en form for livspraksis.

I) Interaktion. Med en mærkbar undtagelse i brevveksling var kommunikationsvejen i de førelektriske medier og deres kunstneriske brug altovervejende ensrettet, nemlig fra en afsender til én eller flere modtagere. Selv om dette vilkår videreføres i de fleste former for massekommunikation - trykt som elektrisk - udfordres det med telegraf og telefon og nu i særdeleshed internettet, der fusionerer masseudbredelse med individuelle kommunikationsformer. 1900-tallets kunst og kunstscene må tilsvarende siges at have været domineret af envejskommunikation - kunstner laver værk, der reciperes af beskuer - men samtidig har det været en fast bestanddel af avantgardernes kunsten-ud-i-livet-projekt, at forskellen kunstner-recipient skulle nedbrydes. Når Benjamin analyserer filmens mediemæssige egenskaber, griber han allerede til Brechts episke teater, hvor orkestergraven fyldes, og beskueren inddrages i det nu mere præsenterede end repræsenterede sceneri, en udjæuning af rolleforskelle, der angiveligt modsvares, når filmen gør de forbipasserende til statister og i øvrigt også, når avisens forvandler sine læsere til forfattere.44 Det er da denne tradition for interaktion, telenærværs- og cyborgkunsten gør helt fænomenologisk, idet den tillader beskuer-brugeren at intervenere direkte i værkernes fysiske miljøer,

hvadenten det er gennem teledirigeret havevanding eller udløsning af en fremmed krops muskler.

2) Realtid. I de klassisk moderne medier og deres artistiske udforskning er tiden noget, der fortrinsvis repræsenteres i imaginære former for 'størknet' tid. Mest indlysende størknet er billedets tid, hvorimod tekst, drama og musik på mere kompleks vis henviser til andre imaginære tider gennem den realtid, de altid udfolder sig i. Med opkomsten af fotografi, telefon, lydreproduktion, film og tv presser den reelle tid sig imidlertid anderledes på i medier og kunst, enten i skikkelse af fæstnet fortid eller - for kunstens vedkommende mest radikalt - i reel nutid. Med eller uden brug af mediering søger avantgarderne tilsvarende igen at indkorporere en form for realtid i deres projekter, lader objekter præge af forgængelige materialer ( $\mathrm{fx}$ Beuys), musik af virkelighedens lyde ( $\mathrm{fx}$ Fluxus), film af uredigerede forløb (fx Warhol), happenings af virkelige lokaliteters tid (fx situationisme). Når man på det seneste iagttager skuespillere skifte mønstre foranlediget af øjeblikkelige konstellationer i en fjern myretue eller Orlan indbygge kunsthistoriske forbilleder i sin foranderlige krop, er det fristende at se en videreførelse af denne avantgardistiske realtid.

3) Virkelighed-krop-teknologi. For de førelektriske medier gælder det, som allerede antydet, at omverdenens fænomener alene repræsenteres med et simuleret nærvær, og samtidig at dette nærvær modtages med fjernsanser og hjerne. Billedkunstnens udforskning af denne mediering $\mathrm{i}$ dens mest simulerede, autonome og refleksionsomgærdede skikkelse er det nu fristende at koble med Benjamins aura-begreb, en term han netop forbinder med en afstandspræget kontemplation af tingenes tilsynekomst, mediegengivet eller ej. Efter udbredelsen af den mekaniske fotoreproduktion, især dens filmiske version, mener han imidlertid, at denne afstandsbetingede og optiske kontemplation sløjfes til fordel for en taktil nærhed, der modtages mere adspredt, og som han, under indvirkning af wienerkunsthistorikeren Alois Riegls neo-hegelianisme, sammenligner med erfaringen af den angiveligt mest arkaiske kunstform, arkitekturen. Neo-arkaismen til trods indebærer denne bevidst- 
hedsnedtonende og kropsappellerende nærhed imidlertid ikke et rent tilbage-til-naturen, tværtimod er den uløseligt sammenbygget med den kamerateknologi, den fremmanes igennem - en instrumentafhængighed, der sammenlignes med kirurgens indtrængning i kroppen.45 Selv om omverdenen selvfølgelig ikke bliver egentligt håndgribeligt nærværende i filmens mediering, omtaler Benjamin altså nærmest filmmediet, som om det allerede var blevet en form for telenærvær, ligesom hans alliance kropslig nærhed og teknologi foregriber cyborgen. Hans karakteristik minder derved også om McLuhans 'elektriske tidsalder', for her opfattes de elektriske medier som en udvendiggørelse af menneskets centralnervesystem, så den klassiske modernitet med dens mekanik, afstande og fragmentering imploderer og erstattes af et neotribalt, mytisk allestedsnærvær, den berømte globale landsby. ${ }^{46}$ Avantgarderne må igen siges at flette sig ind i dette på én gang højteknologiske og neo-arkaiske felt, for ikke blot betjener de sig ofte af elektriske, fotografiske og masseproducerede medier (tænk på Duchamp, Fluxus, popkunst), de vender sig også helt væk fra medierne i deres produktion af en ofte teknologiledsaget kropsappel. Det sker særlig markant i ready-mades'ne, industrielt forarbejdede objekter, der bliver så tingslige, at semiosens passage tilstoppes, og betydningsdannelsen forskydes mod brydningen mellem gammel og ny kontekst. I det perspektiv kan den selvlysende kanin Alba opfattes som en let fremhjulpet ready-made, hvis øjeblikkelige betydning genereres af gnidningen mellem fri natur, bioteknologi og kunst.

\section{Tilbage til fremtiden - og ud af kunsten}

Når man konfronterer sig med disse mange forskydninger i I900-tallets kultur, hvor medierne og kunsten gennem teknologiens mellemkomst præges af interaktion og realtid, krops- og virkelighedsnærvær kan man ikke undgå at stille spørgsmålet: Lever kunsten og æstetikken videre som uantastede begrebslige domæner, således at det kun er deres genstandes praksis, der forskyder sig, eller peger disse udviklinger mod en så gennemgribende ændring af det praktiske felt, at de videnskaber, der forholder sig til dette, også forandres og måske knap nok kan opretholde deres hidtidige grænser og ontologier?

For at tilnærme sig dette vanskelige spørgsmål kan man først gå deskriptivt til værks og bemærke, at de to domæner, cyborgen og telenærværet fører ind i kunstfeltet - nemlig på den ene side teknologien, på den anden side det organiske liv - længe har været anset for fremmede i kunstnerisk og æstetisk sammenhæng. Kunstværket og den æstetiske erfaring kunne nok reflektere teknologi og organisk liv på auraens afstand, men teknologiens funktionalitet og livets foranderlighed, interesser og etiske hensyn skulle helst ikke blande sig i selve det æstetiske domæne, der skulle forblive fri for nyttehensyn og etisk stillingtagen. Ifølge denne logik bør imitationens primitive grunddrift, Pygmalions begær efter at bringe sin elfenbenskvinde til live, helst forblive en uindfrielig utopi, for i det øjeblik skulpturen faktisk krydser grænsen til de levendes land, ophører dens identitet som kunst.

Kunstens fjernhed fra det organiske liv understreges af, at æstetikken siden Kant og Hegel ofte ser naturen som en meningstom grund, hvorpå den kunstneriske vision med desto stærkere virkning kan projiceres. Ikke desto mindre vil jeg hævde, at teknologi og kunst begge har forholdt sig til naturens bevægelseskræfter, dens dynamik, men at de samtidig har gjort det på hver deres specialiserede måde. Som protese for kroppen har teknologien, støttet af sit begrebslige bagland, naturvidenskaben, gjort effektiv brug af naturens bevægelseskræfter, og dog har den kun anvendt de af dem, der fremstod mekaniske, maskinelle og i sidste ende døde - en forståelsesramme, der som tidligere antydet har strakt sig helt ind i kroppen, der i lægevidenskaben begribes ud fra samme maskinelle paradigme som sin protese. Kunsten og dens begrebslige bagland æstetikken, derimod, har forholdt sig til de mere turbulente, uforudsigelige og på sin vis levende af naturens bevægelseskræfter, et tæppe af kaotisk singularitet, der om ikke andet gennem kunstnerens frie greb forvandles til intenst liv, jævnfør romantiske bevægelsesmetaforer, som at kunsten skal bevæge, røre, henrykke og leve. Eftersom kunsten imidlertid stadig fremstår som protese for sanseapparat og hjerne, har denne mere levendegjorte natur på sin side alene 
figureret som en imaginær genskabelse, der nok har bevæget det frie sind, men ikke i nogen reel forstand vekselvirket med den fysiske og kropslige omverden.

For mange humanistiske iagttagere er denne arbejdsdeling kun blevet skærpet af, at teknologiens eksplosive vækst i I900-tallet har truet med at instrumentalisere væsensfremmede kultur- og livsområder ved at behandle dem efter samme mekanistiske paradigme som det, der er udviklet i naturvidenskaben. Heideggers begrædelse af en natur, der er blevet blot og bar lagerbeholdning for teknologien, Foucaults kritik af moderne magt- og overvågningsteknikker, Lacans og Merleau-Pontys stempling af perspektivet som en rationel konstruktion fjern fra sansningen, Adornos og Greenbergs skepsis over for massekulturens fordummende industrier - alle er eksempler på en teknologiskeptisk humanistisk kultur, der bekymres over teknologiens infiltration af det almindelige liv og stiller spørgsmålstegn ved identifikationen af teknologiens fremskridtshistorie med samfundets. Herimod opstilles kunsten og den æstetiske erfaring som et særligt autentisk domæne, der er i kontakt med menneskets undertrykte behov, og som kan levere den ene kritiske platform, hvorfra teknologiens perverterede rationalitet kan inddæmmes.

Men hvad nu, hvis den klassisk moderne arbejdsdeling mellem teknologi og kunst, og mellem naturvidenskab og æstetik, er ved at miste sin gyldighed - hvis teknologien ikke kun bemestrer en mekanisk og død natur, men indoptager og videreudvikler nogle af naturens mere komplekse former for dynamik, og hvis kunsten tilsvarende ikke kun genskaber en imaginært levende natur, men omsætter sine æstetiske eksperimenter i noget, der begynder at ligne funktionelle og mere reelt levende sammenhænge? Faktisk var Heidegger inde på et lignende fremtidsscenarie i sin ellers så teknologiskeptiske analyse i skriftet Die Technik und die Kehre (1962). 47 Heidegger tager her udgangspunkt i tanken, at kunst og teknologi oprindelig var del af det samme håndværksmæssige fællesdomæne - den græske technè og den latinske ars - og at de først sidenhen, især efter middelalderen, blev spaltet ud i autonom, selvsmagende finkunst og brugsrettet, kynisk teknologi. Kun ved at gentilføre teknologien noget af kunstens oprindelige viden om det værende og samtidig bibringe kunsten noget af teknologiens brugssammenhæng kommer vi ifølge Heidegger ud af den overhængende fare, civilisationen har bevæget sig ud i, og som nu truer også mennesket med at blive lagerbeholdning, Bestand, for teknologien. I Heideggers tanke om et kommende fællesdomæne for kunst og teknologi, der genopvækker præsokratiske tilstande, møder vi altså en cyklisk historiografi, der slående minder om Benjamins og McLuhans tidligere omtalte cykliske vendinger, henholdsvis mekanisk reproducérbarhed som genkommet adspredt taktilitet à la arkaisk arkitektur og elektrisk mediering som neotribalt, mytisk allestedsnærvær.

Selv om jeg finder det meget befordrende at tænke cyborgens og telenærværets tidsalder som en epoke, der generelt reaktualiserer det primitive - det primitive forstået som bl.a. anti-nominalisme, indeksikalsk semiose, hybriditet, animation af materien - er det spørgsmålet, om dette primitive begrænser sig til kulturens domæne og ikke også åbner for dybder i vores biologiske fortid. Det er her, det posthumane kommer ind, for cyborgen udvider også den postmoderne kulturs rækkevidde ud over det ekstrasomatiske og tegnbundne og får den til at indgå fysiske alliancer med kroppe og organismer, der herved ændres helt ind i generne, hvorfor det posthumane altså kommer til at minde mindst lige så meget om en genkommen naturhistorie som om tidligere faser $i$ den skrøbelige ekstra-anatomiske fernis, der går under navnet kultur. I dette perspektiv fremstår sanseapparatet og hjerne, som medier og kunst jo kan ses som proteser for, som de biologiske arters modernitet, der opbygger en imaginær afstandsverden for organismerne, hvorimod forplantning, fordøjelse, stofskifte, berøring og respiration, kort sagt den direkte omverdensudveksling, der nu rekonstrueres artificielt i cyborgen og telenærværet, udgør biologiens primitive. Til biologiens modernitet må også tilskrives den udspaltning $\mathrm{i}$ artsmæssige grene, som siden de flercellede organismers opkomst har hindret fri genudveksling på tværs af arterne, men som nu gennem bioteknologiens mellemkomst øjensyn- 
lig atter opblødes, hvorved posthumaniteten altså også bliver neoprimitiv gennem sin artificielle genspilning og videreudvikling af den artsmæssige promiskuitet, der fandt sted i urhavet, inden de flercellede organismer accelererede for en halv milliard år siden. En sådan ejendommelig samtidighed mellem glitrende teknologisk fremtid og dyb, naturhistorisk fortid er akkurat, hvad earth art-kunstneren Robert Smithson forbinder med vores æra. Ifølge Smithson, der altså udvider rækken af cykliske historiografier, er den højteknologiske kultur ramt af entropi, der gør den til en art baglæns evolution, en "bagudskuende fremtid", hvor synet blokeres af hermetiske overflader, det falske făr større 'virkelighed' end det sande, skriften kollapser i geologi, og en fossileret seksualitet fremstår i mødet mellem 'I984' og 'I million f.Kr.' 48

Læseren vil måske synes, at denne sammenskrivning af Benjamins, McLuhans, Heideggers og Smithsons neoprimitive cykliciteter og udvidelse af dem i et biologisk perspektiv efterhånden har tiltaget sig en smagløs apokalyptisk undertone, men fremfor at neddæmpe denne vil jeg hellere gøre den tydelig - i håbet om derigennem at kunne afmytificere og afideologisere den en smule. Apokalypse betyder 'afsløring', nemlig fjernelsen af den semiotiske hinde, bibelens ord, der hidtil har afskærmet os fra at kunne skue den guddommelige virkelighed direkte, sådan som det endnu var muligt $i$ de første paradisiske tider. Hvis man nedtoner det frelsende moment $i$ denne igen cykliske historiografi og ihukommer, at apokalypsen ligesåvel indebærer ragnarok forud for frelsen, er det fristende at forbinde denne bortfjerning af semiosen og mediet med opkomsten af det posthumane, epoken, der netop kendetegnes ved, at cyborgen og telenærværet gennemhuller semiosens og mediernes barriere til fordel for et teknologiunderstøttet fysisk og kropsligt nærvær, der genkalder evolutionens tidligste, om man vil paradisiske stadier. Ved et let optikskifte lader ideen om en sådan apokalyptisk gennemhulning af semiosens hinde sig desuden genfinde i Hegels tanke om den absolutte viden, bevidsthedens yderste stadium, hvor subjekt og objekt bliver ét, foruden i mangen psykoanalytisk kulturkritik, fra Lacan og Kristeva til Hal
Foster.49 I sidstnævnte peger den paradisiske virkelighed, der punktvis flænger semiosens tæppe, dog ikke mod en artsmæssig eller kulturel, men mod en individuel fortid, nemlig den førsproglige tilstand, der har sit tyngdepunkt i spædbarnets symbiose med moderen, altså igen en tilstand, der kan kaldes primitiv, idet den omhandler nærhed, berøring og umedieret stofudveksling.

Efterlyser man forslag til, nærmere hvordan en apokalyptisk utopi lader sig samtænke med en forenet kulturel og biologisk evolutionshistorie, kunne man passende fremdrage den jesuitiske palæontolog Pierre Teilhard de Chardin og dennes reception hos den engelske computerkunstner Roy Ascott. ${ }^{\circ}$ Teilhard de Chardin betragtede den biologiske evolution som et forum, der modvirker universets almindelige tilbøjelighed til entropi, ikke mindst ved på emergent vis at akkumulere bevidsthed. Akkumulationen har sit foreløbige højdepunkt i mennesket, men Teilhard forudså, at menneskets individuelle bevidsthedskoncentrationer vil forbindes med hinanden og skabe en bevidsthedssfære, noosfæren (fra græsk noos=sjæl), der vil konvergere mod det såkaldte omegapunkt, en art ren transcendens. Roy Ascott identificerer nu noosfæren med fremtidsforskeren Peter Russells begreb "den globale hjerne", og ikke ulig McLuhans idé om de elektriske medier som et udvendiggjort nervesystem forbinder han yderligere begge med informationssamfundets netværker af computere, hvad han betegner "det telematiske favntag”. I særdeleshed opfatter han sine egne interaktive telematiske projekter som vordende arbejdsmodeller, hvor skellet mellem kunstner, beskuer og værk udviskes, og kunst, teknologi og intuition potentielt forenes i den gensidigt forhandlede tilblivelse, der tager del i den globale bevidsthed.

Utopikere som Teilhard og Ascott er næsten uforskammet lette at kritisere - især kan de dadles for at være optimistiske i en himmelråbende grad og vægte det bevidsthedsmæssige på det kropsliges bekostning - men kan man abstrahere herfra, mener jeg, deres ideer på et mere principielt, strukturelt plan udgør nyttige ingredienser $\mathrm{i}$ en fremtidspejling, herunder ikke mindst for kunstens og æstetikkens status i det posthumane. Utopiens forhåbning er jo, at et eller 
andet, nutiden savner, i fremtiden vil kunne indfries, hvorved de nødforanstaltninger, hvormed man hidtil har dæmmet op for savnet, overflødiggøres - det være sig fængsler, psykiatriske hospitaler, penge, klasseskel eller, som nu i tilfældet Apokalypsen, medier. Medier kan som sagt, som proteser for sanseapparat og hjerne, opfattes som imaginære nærvær, erstatninger, der sættes ind på faktiske fraværs plads. Men når nu fællesnævneren i kristendommens, Hegels og den psykoanalytiske kulturkritiks utopier er en eller form for umedieret nærvær, og vi yderligere har set, at telenærvær og cyborgs synes at tilbyde teknologisk understøttede nærvær, der nedbryder kulturens hidtil skærmende hinde mellem tegn og ting, er det så ikke fristende faktisk at opfatte telenærvær og cyborgs som i hvert fald en del af svaret på utopien - en kobling, der understøttes af Benjamins, McLuhans, Heideggers og Smithsons quasiapokalyptiske læsninger af postmoderniteten som i én eller anden forstand neoprimitivistisk, altså præget af kropsligt nærvær og indeksikalske forbindelser mellem tegn og ting?

En sådan læsning skal igen opfattes mere køligtstrukturel end jubilerende (uagtet at flere af de ovennævnte genmodificerende kunstnere faktisk grupperede sig i en New York-udstilling kaldet Paradise Now!), og alligevel kan jeg ikke se bort fra muligheden for, at posthumaniteten indebærer oparbejdelsen af nye former for inter- og intrasomatisk kompleksitet, der måske svækker behovet for tidligere kulturelle udtryksformer. Hører kunsten og den æstetiske erfaring så heriblandt? For mig at se, kommer det meget an på, hvor elastisk deres definitionsradier opfattes. Tidligere $\mathrm{i}$ artiklen har jeg plæderet for, at kunsten og den æstetiske erfaring i deres klassisk moderne betydninger må ses som nøje forbundet med dels fjernsanserne og deres proteser medierne, dels den autonome interesseløse, legende refleksion herover - hele det felt, Benjamin indbefattede under aurabegrebet - men da vi også har set, hvordan telenærvær og cyborgs overlejrer, hvis ikke opløser både det specifikt mediemæssige, fjernsansernes dominans og den autonome refleksion, er det i hvert fald indlysende, at man må operere med kraftigt udvidede definitioner, hvis kunst og æstetisk erfaring fortsat skal være rammende kategorier til inddæmning af samtidens kulturelle, eller efterhånden cyborg-agtige fænomener.

Som jeg har argumenteret nærmere for andetsteds, nærer jeg selv tvivl, om kunstbegrebet faktisk vil kunne følge med de hastigt muterende praksisser, der breder sig inden for de heterogene felter, der stadig søges sammenbragt og indhegnet $i$ dets navn. ${ }^{51}$ Kunst, som jeg opfatter den, er uløselig forbundet med en metafysisk erfaring, en afsøgning af et imaginært hinsides, der næres af kløften til et aldrig indfrieligt nærvær. Men i de kunstgenrer, der udfolder sig i telenærværets og cyborgens regi, fyldes denne kløft, hvorved det imaginært hinsides trækkes ned i tidens og rummets reelle muligheder, så kunstværdien forskydes til en produktiv konflikt mellem, hvad vi faktisk oplever, og vores forventning om, 
hvilket imaginært rum et kunstværk stadig bør fremskrive. Derfor kan Eduardo Kac lægge vægt på, at den selvlysende kanin Alba, ligeså meget består i de diskursive felter, den indgår i, som i dens kropslige nærvær, for dette nærvær har mættet det imaginære med kød og blod $\mathrm{i}$ en grad, at kaninen er blevet mere virkelighed end kunst. Eller anderledes sagt: efter kaninen er blevet virkeliggjort, indskrænkes kunst og æstetik til blot én af mange mulige indfaldsvinkler til den, og ovenikøbet én, der lever symbiotisk i spændingsfeltet med de andre, hvad skandalesuccesen med det franske forskningslaboratiorium bevidner.

Men selv om kunstbegrebet muligvis en dag vil halte bagefter samtidens nyskabende praksisformer, er dette stadig et futuristisk scenarie, der på ingen måde mistænkeliggør samtidskunstens erfaringer. Tværtimod tror jeg i lighed med de historiske avantgarder på, at kunsten besidder et unikt kritisk potentiale, der måske mere end nogensinde er brug for, hvis den posthumane æra skal virkeliggøres som blot en anelse mere utopi end dystopi. Hvad kunsten stadig er god til i forhold til så mange andre kulturområder, er at eksperimentere, at unddrage sig vanetænkning, at nægte at lade sig instrumentalisere af andre interesser, og at strukturere komplekse stofområder på formmæssigt slående og samtidig ikkelukkende måder. Disse evner er i vid udstrækning forligelige med Kants beskrivelse af den æstetiske erfaring, og da denne er modelleret efter naturens angiveligt utvungne og frie virkemåde, virker de måske særligt egnede, når de nu på avantgardemanér skal udfoldes i en livspraksis som cyborgens, der jo faktisk udgøres af en form for natur, ovenikøbet en natur, der gennem sin teknologiske modifikation er udsat for den proces, man fremfor alt forbinder med kunst: skabelse.

Problemet er imidlertid igen springet fra interesseløs fantasi til virkelighed: at selv om også livet $i$ grundlæggende forstand kan hævdes at være interesseløst - ikke bør instrumentaliseres - så er det egentlig kun interesser, der kan legitimere, hvorfor og hvordan kulturen skal påvirke organismer. Og sådanne interesser har hidtil kun virket tilforladelige, når de underordner teknologisk modificerede orga- nismer menneskets normalbehov - dvs. helbredelse og næring - hvorimod de mere frie, æstetiske og især forbedringsmøntede eksperimenter, kort sagt repertoiret, der må antages at høre til den posthumane æra, er vanskelige at finde legitimation for. Kacs krav om etik, ansvarlighed og kærlighed virker her som en uden tvivl nødvendig, men på ingen måde tilstrækkelig betingelse for at udvikle nye organismer, cyborgs, for etikken omhandler kun, at disse cyborgs får acceptable livsbetingelser, ikke grundspørgsmålet om, hvorfor de overhovedet skal blive til. Ud fra en idé om øget mangfoldighed som et universelt gode? Ud fra en idé om øget legemlig kapacitet som livets mening? Hvad svarene end kan være, vil de på én eller anden måde angå en mening, en hensigt, et formål med vore interventioner i evolutionen. $\mathrm{Og}$ således tror jeg ikke, vi undgår at revurdere spørgsmålet om en teleologisk dimension i naturen, i særdeleshed den del af den, der nu åbner sig for kulturel manipulation.

\section{Noter}

I. Gotthold Ephraim Lessing, Laokoon [I766], i idem., Lessings Werke, Bd. 3, Berlin og Weimar: Aufbau-Verlag, I975, især pp. I70-75, I86-96, 246-65 og 293-96.

2. Clement Greenberg, "Towards a Newer Laocoon" [1940], i Charles Harrison og Paul Wood (eds.), Art in Theory 1900-199o: An Anthology of Changing Ideas, Oxford og Cambridge (Mass.): Blackwell, I992, pp. 554-60.

3. Marshall McLuhan, Understanding Media: The Extensions of Man, London: Routledge, 1997 (I964), p. 7.

4. <www.ekac.org>

5. <http://telegarden.aec.at>

6. McLuhan (1997), passim.

7. Se Marsilio Ficinos kommentar til til Platons Symposion, V,II, i Albert Hofstadter og Richard Kuhns (eds.), Philosophies of Art and Beauty: Selected Readings from Plato to Heidegger, Chicago: University of Chicago Press, I964, pp. 2I7-I9.

8. Alexander Gottlieb Baumgarten, Theoretische Ästhetik. Die grundlegenden Abschnitte aus der "Aesthetica"(1750/58) (overs. og ed. Hans Rudolf Schweizer), Hamburg: Felix Meiner Verlag, I983.

9. Immanuel Kant, Kritik der Urteilskraft [I793] (ed. W. Weischedel), Frankfurt a.M.: Suhrkamp Verlag, I974 (1957), pp. 237-4I.

Io. Robert A. Heinlein, The Fantasies of Robert A. Heinlein, New York: Tom Doherty Associates, 1999, pp. I25-212. Eduardo Kac, "Telepresence Art" [1993], på <www.ekac. 
org.>

II. Marvin Minsky, “Telepresence”, i Omni, juni I980, pp. $45-52$, cit. ibid.

I2. Cit. ibid.

I3. I sammenhæng med udstillingen Beyond Borders.

I4. På udstillingen Metamachines: Where is the Body?

I5. Citeret i Stephen Wilson, Information Arts: Intersections of Art, Science, and Technology, Cambridge (Mass.) og London: MIT Press, 2002, p. 535 .

I6. Wilson (2002), pp. 535-36.

17. Artikel i YLEM Newsletter, cit. Wilson (2002), p. 529.

I8. <http://telegarden.aec.at>

19. Jean Baudrillard, Simulations (overs. P. Foss, P. Patton og Ph. Beitchman), New York: Semiotext(e), I983, p. 54. Kac [1993].

2o.Paul Virilio, Synsmaskinen (overs. Niels Brügger og Orla Vigsø), København: politisk revy, 1989 (fr. I.ed. I988), pp. II7 og I23.

2 I. Ibid.

22. Ibid.

23. Abraham A Moles, "Design and Immateriality: What of It in a Post-Industrial Society?", i Marco Diani (ed.), The Immaterial Society: Design, Culture and Technology in the Postmodern World, New Jersey: Prentice-Hall, I992, pp. 27-28, cit. Kac [1993].

24. Peter Schepelern, Lars von Triers film. Tvang og befrielse, København: Munksgaard Rosinante, 2000, pp. I58-64.

25. Wilson (2002), pp. I82-88.

26.Jacob Wamberg, "Kroppen som posthuman skulptur. Om Stelarcs performances”, i Anders Troelsen (ed.), Synsvinkler på skulpturen. Antologi om skulpturanalyse, Århus: Aarhus Universitetsforlag 2002, pp. 346-48.

27. Arthur og Marielouise Kroker (eds.), Digital Delirium, New York: St. Martins Press 1997, p. 197.

28. Feltet mellem medier og cyborgs spores anskueligt $\mathrm{i}$ Niels Brügger, "Krop, teknik og medier. Med Mauss, McLuhan og Virilio som vejvisere", i Christa Lykke Christensen, Anne Jerslev og John Thorup (eds.), Kroppe - Billeder - Medier, København: Borgens Forlag, I998, pp. 9-25. 29. Se Susan Blackmore, The Meme Machine (forord: Richard Dawkins), Oxford I999.

30. Arthur og Marielouise Kroker, "Memetic Flesh in $\mathrm{Cy}-$ ber-City”, i Kroker (1997), pp. I66-67.

3I. John Appleby, "Planned Obsolescence: Flying into the Future with Stelarc", i Joanna Zylinska, The Cyborg Experiments: The Extensions of the Body in the Media Age, London og New York: Continuum, 2002, p. I04. Bruce Greenville (ed.), The Uncanny: Experiments in Cyborg Culture (udst. kat.) Vancouver: Vancouver Art Gallery og Arsenal Pulp Press, 200I, p. 29.

32. Wilson (2002), pp. 98-99. Steve Tomasula, "Genetic Art and the Aesthetics of Biology", i Leonardo Electronic Almanac, 35, 2 (2002), p. I4I.

33. Ibid., p. I42.

34. Steve Baker, “Haunted by the Animal”, i Tate Magazine, September 200I, gengivet på www.ekac.org.

35. Eduardo Kac, "Transgenic Art”, i Leonardo Electronic Almanac, 6, II (1998), genoptrykt i Ars Electronica 99: Life Science, Wien og New York: Springer Verlag, I999, p. 292. 36. Wilson (2002), pp. 96-98.

37. Tomasula (2002), p. 138.

38. Fred Botting og Scott Wilson, “Morlan”, i Zylinska (2002), p. 158

39. Ibid, p. I50.

40. Wamberg (2002).

4I. Stelarc, "Towards a Compliant Coupling: Pneumatic Projects, I998-200I”, i Zylinska (2002), pp. 73-78.

42. Walter Benjamin, "Das Kunstwerk im Zeitalter seiner technischen Reproduzierbarkeit" [1936], i Das Kunstwerk im Zeitalter seiner technischen Reproduzierbarkeit: Drei Studien zur Kunstsoziologie, Frankfurt a.M.: Suhrkamp Verlag, 1974, pp. 9-63. McLuhan (1997).

43.Peter Bürger, Theorie der Avantgarde, Frankfurt a.M.: Suhrkamp Verlag, 1974.

44.Benjamin (1974), p. 32.

45.Benjamin (1974), pp. 36 og 46-47.

46. McLuhan (1997), pp. 24-25.

47. Stuttgart:Verlag Günther Neske, 1996.

48. Robert Smithson, "Entropy and the New Monuments"[1966], i Nancy Holt (ed.), The Writings of Robert Smithson, New York: New York University Press, 1979, pp. 9-I8.

49.G.W.F. Hegel, Phänomenologie des Geistes [1807] (eds. H.-F. Wessels og H. Clairmont), Hamburg: Felix Meiner Verlag, 1988. Jacques Lacan, The Four Fundamental Concepts of Psycho-Analysis (ed. Jacques-Alain Miller, overs. A. Sheridan), Harmondsworth: Penguin Books, 1977 (fr I. ed. 1973). Julia Kristeva, Revolutio in Poetic Language (overs. M. Waller, intr. L.S. Roudiez), New York: Columbia University Press, 1984 (fr. I. ed. 1974). Hal Foster, The Reurn of the Real: The Avant-Garde at the End of the Century, Cambridge (Mass.) og London: MIT Press, 1996.

5o.Pierre Teilhard de Chardin, The Phenomenon of Man (overs. Bernard Wall, intr. Julian Huxley), London: Collins, I959 (fr. I. ed. I955). Edward A. Shanken, “Technology and Intuition: Roy Ascott”, i Leonardo Electronic Almanac, Io, 3 (I997).

5I. "Kunstbegrebets forældelse? Evolutionen som vilkår og udfordring", i Hans Dam Christensen, Anders Michelsen og Jacob Wamberg (eds.), Kunstteori. Positioner i nutidig kunstdebat, København: Borgen, I999, pp. I8I-2II. 
